\title{
DESAFIOS DE ESTUDANTES CAMPONESES
}

Francisco José de Macêdo ${ }^{1}$

Ao falar de resistência

Se fala em perseverança

Da força que vem do além

No sonho de uma criança

Em ter um futuro brilhante

Ele luta a cada instante

Sem perder a esperança.

Esse é o aluno do campo

Que traz na sua bagagem

Reflexo de um mundo novo

Marcado por uma imagem

Uma identidade racista

Fazendo com que persista

Com esforço e coragem.

A vida de um acadêmico

É um processo desafiador

$\mathrm{O}$ aluno tem que encarar

Lutando contra o opressor

Em uma luta constante

Sem parar nem um instante

Com firmeza e vigor.

Sabendo dos desafios

Da grande revolução

O impacto que tudo causa

Por uma capacitação

\footnotetext{
${ }^{1}$ Graduando do terceiro período do curso de Licenciatura em Educação do Campo - Ciências da Natureza (LEdoC) (UFPI), campi Teresina (PI). E-mail: franciscoacademico@gmail.com
} 
O jovem aposta o que tem

Buscando entender também

O porquê da exclusão.

Que é muito temerosa

Rouba o que é nosso direito

Só vê o lado oposto

Fugindo da lei o conceito

Os direitos não são iguais

O aluno do campo banais

É visto como sujeito.

Está contido na lei

Da nossa constituição

Como forma de artigo

O direito à educação

Direito Constitucional

O ensino é um direito igual

Rege na legislação.

Para muitos é bobagem

Achar que o campo existe

Que esse espaço é de rico

E que o camponês não insiste

Nas lacunas desta vida

Cheia de curva e descida

É aqui que a luta resiste.

Temos em frente a missão

Algo muito cognitivo

Como forma de padrão

Em busca de um objetivo

Encarar a dura realidade

Lutar em coletividade 
Por um ensino inclusivo.

Que fique subentendido

Nossa luta é permanente

Pelo bem do coletivo

Uma corrente de gente

Um brilho amplo e concreto

Ligados em um projeto

Vencer com o consciente.

Não estamos aqui pra badernar

Essa não é a nossa arte

Temos consciência e limite

E cumprimos nossa parte

Mesmo sendo desprezados

Refém do ódio do estado

Que de nóis só faz descarte.

Aqui a onda é vencer

Mesmo com dificuldade

Encarar os preconceitos

Lutar por dignidade

Não temos medo da luta

Temos coragem e conduta

Paz e complexidade.
A Educação do Campo
É um grupo animado
Um conjunto de pessoas
Que caminha lado a lado
Visando o bem comum
Ao bem está de cada um
É esse o nosso legado. 